\title{
EMBERI JOGI ENCIKLOPÉDIA
}

Emberi jogokkal mindennap találkozunk: a politikai nyelvben éppúgy, mint a jogiban, de mára a mindennapi nyelvben sem ritka, hogy valaki - okkal, ok nélkül - emberi jogának tart valamit. Az emberi jogokra való minden ilyen hivatkozásban közös, hogy emberi jogon mindig fontos, erős, az egyént feltétlenül megillető jogot értünk és igénylünk. Minden fontos társadalmi cél előbb-utóbb emberi jog lesz: így van (emberi) jog a vízhez, az egészséges környezethez, az élelmezéshez, az egészséghez, a fejlődéshez és így tovább. Az emberi joggá minősítés a követelés vagy igény fontosságát nyomatékosítja, mivel az emberi jog feltétlenül biztosítandó jogot jelent.

Az emberi jogok modern eszmetörténete a 18. század végétől kezdődik; a természetjogot ideértve ez a történet azonban sokkal hosszabb. Mégis, gyakorlati és tételes jogi jelentősége a modern alkotmányos államokban és a nemzetközi jogban a második világháború után lett; ennek egyik oka az alapjogi alkotmánybíráskodás elterjedése a világon (különösen a 20. század utolsó harmadában), a másik az emberi jogok nemzetközi jogi védelme, különösen a regionális emberi jogi bíróságok - mint az Emberi Jogok Európai Bírósága és az Amerikai Emberi Jogi Bíróság - egyre hatásosabb tevékenysége. Az emberi jogi érvelés a világpolitikában nem követi ezeket szorosan, de mindenképpen figyelemre méltó, hogy az emberi jogok (különben szelektív) védelme a külpolitikájában - retorikai fogásként, ritkábban őszintén - különben nehezen magyarázható lépések igazolására vonzó érv.

Jogászi-jogi szempontból az emberi jogok minősítése sokféle lehet. Az ünnepélyes, de jogilag nem kötelező deklarálástól az alkotmányosan garantált és jogi eljárással védett alapjogokig sok minden nevezhető emberi jognak. Külön kérdés a nemzetközi jogban biztosított emberi jogok jogi jellege, mert nem illik a nemzetközi jognak az államok egymás közötti kapcsolatát szabályozó rendszerébe: az emberi jogokat védő immár igen nagy számú (száz fölötti) nemzetközi egyezmény nem állam és állam kapcsolatát szabályozza, hanem az állam és az ember, döntően saját állampolgára viszonyát, amely hagyományosan a nemzetközi jog szerint az állam „belügye” (belső joghatóságában tartozó kérdés), amelybe más államok nem avatkozhatnak be, egyáltalán jogilag nem is foglalkozhatnak vele, lévén az állam saját - nemzetközi jogi szempontból: belső - jogrendszerére, azaz szuverenitására tartozó tárgy.

Az emberi jogokat a jogrendszernek, államnak feltétlenül biztosítania kell: a biztosítás lényege, hogy az emberi jogokat - ezek mindig normák - a jogrendszernek és kivált a joghoz kötött állami szerveknek kell pozitív jogként megvaló- 
sítaniuk és megtartaniuk. Ha a tortúra tilalma emberi jog, akkor az állam egyetlen jogszabálya sem engedhet meg kínzást, állami szerveinek pedig meg kell tiltania alkalmazását, s e tilalom érvényesülését jogi eszközökkel biztosítania kell.

Mindezekről a kérdésekről és még sok minden másról olvashat az érdeklődő a nemrég megjelent Emberi jogi enciklopédiában. Az enciklopédia új múfaj az emberi jogi összefoglaló müvek között a magyar szakirodalomban. Természetesen jelentek meg korábban az emberi jogokról szóló összefoglaló mủvek, mint Szabó Imre úttörő, 1948-ban megjelent Az emberi jogok mai értelme címü könyve, továbbá Kovács István és Szabó Imre Az emberi jogok dokumentumokban (1976) címủ két kiadást megért igen fontos gyüjteménye a szocialista korszakban, utóbb a Halmai Gábor és Tóth Gábor Attila szerkesztette Emberi jogok címü átfogó tanulmánykötet. A méltányosság kívánja, hogy említsük Kis János Vannak-e emberi jogaink? címü, annak idején szamizdatban, később pedig „rendes” kiadásban megjelent könyvét, annak ellenére, hogy szerzője filozófus (vagyis nem jogász).

Enciklopédia formában készült kiadvány magyar nyelven még nem született, ezért a kötet hiánypótló, egyértelmúen alapirodalomnak tekinthető az emberi jogok bemutatása és elemzése tekintetében. A hatvanhét főből álló szerzői kollektíva százkét tanulmányban (egyenként 4-12 oldal terjedelemben) mutatja be a legfontosabb emberi jogi fogalmakat, intézményeket és dokumentumokat.

Az enciklopédia a következőképpen határozza meg az emberi jogok fogalmát: az emberi jogok magából az emberi mivoltból fakadnak, minden embert feltétlenül, univerzálisan és egyenlöen illetnek meg. Az emberi jogok minden embert egyenként megillető, szubjektív jogok, a jog gyakorlása mindig az ember döntésén múlik. Minden jog valamilyen cselekvés vagy magatartástípus szabadságát biztosítja, így az emberi jogok egyben szabadságjogok (19.).

Az emberi jogok azokat is megilletik, akik nem értenek velük egyet, nem fogadják el öket vagy egy részüket. Az emberi jogok tiszteletben tartása mindig lehetséges, nem függ attól, hogy valaki igényli-e, vagy sem (25.). Az alapvető emberi jogok általában akkor tudnak érvényesülni, ha az egyes jogok korlátozhatók. A korlátozás mércéje a magyar jogban az ún. szükségességi-arányossági teszt. Vannak azonban a nemzetközi jogban olyan jogok, amelyeket semelyik más alapjog vagy alkotmányos cél érdekében nem lehet korlátozni, illetve felfüggeszteni, azaz abszolút jellegüek (26-32.).

Az emberi jogok modern értelemben vett fogalma a 18. században alakult ki. A napjaink emberi jogi felfogását meghatározó jogi dokumentumok (például Bragyova András: Ember és Polgár Jogainak Nyilatkozata [1789]) keletkezésére a felvilágosodás filozófiája, az amerikai és a francia forradalom gyakorolt jelentős hatást. Az emberi jogok kezdetben belső jogi dokumentumokban jelentek meg, és a második világháború végéig nem merült fel annak gondolata - a kisebbségek védelmét kivéve (523.) -, hogy az állam és a polgárai viszonyát a nemzetközi jog szabályozza. 
A nemzetközi emberi jogi jogvédelem a második világháború után indult dinamikus fejlödésnek, és született meg többek között az Emberi Jogok Nemzetközi Törvényének fogalma is (lásd: Lamm Vanda: Egyezségokmányok; Lamm Vanda: Emberi Jogok Egyetemes Nyilatkozata). A dokumentumok célja azonban nem csupán a jogok deklarálása volt, hanem törekedtek arra is, hogy a különféle dokumentumokban foglalt jogok érvényesülése terén is történjen elörelépés. A modern alkotmányokban az alkotmányos jogok katalógusa a legtöbb általánosan elismert emberi jogot alkotmányos jogként tartalmazza, azonban az emberi jog nem mindig alapjog, lehetséges, hogy egyes emberi jogokat az államok rendes törvényei védenek. Az emberi jogok érvényesülésének legfőbb biztosítéka az alapjogok alkotmányos védelme, mely a rendes vagy az alkotmánybíróságok feladata. Az alapjogok bírói védelme az alapjogokat biztosító törvények értelmezésében és alkalmazásában áll. Az alkotmánybíráskodás továbbá meg is semmisítheti az alapjogokat korlátozó jogszabályokat. A jogok biztosításában minden állam saját alkotmányos szabályai szerint jár el (23.). Az emberi jogok nemzetközi védelme és a belső jogokban való érvényesülése tekintetében meghatározó szerepet töltenek be az univerzális és regionális emberi jogi szerződési bizottságok is (lásd: Lamm Vanda: ENSZ emberi jogi szerzödési bizottságok).

Az enciklopédia az univerzális emberi jogi egyezmények bemutatása mellett a regionális szintü nemzetközi együttmüködés, valamint a nemzeti kisebbségek védelmét tartalmazó dokumentumok ismertetésére is kitér (Kovács Ildikó: Emberi Jogok Arab Kartája; Weller Mónika: Emberi Jogok Európai Egyezménye; Kecskés Gábor: Emberi jogok regionális védelme az ázsiai és a csendes-óceániai régióban; Zaccaria Márton Leó: Európai Szociális Karta; Friedery Réka-Horváthy Balázs: Európai Unió Alapjogi Chartája; Szalai Anikó: Nemzeti kisebbségek védelme stb.). A regionális jogvédelmi eszközök célja, hogy tovább erősítsék az univerzális védelmi rendszert (151.).

Az olvasó azonban nemcsak az emberi jogok történeti hátteréről, a kiemelkedő jelentőségű szerződésekről és dokumentumokról, valamint az elméleti alapokról (például Bragyova András: Alapjogok - emberi jogok fogalma; Fekete Balázs: Emberi jogok története és elméleti kérdései stb.), hanem a szervezeti és intézményi keretekröl (Ganczer Mónika: ENSZ emberi jogi intézmények; Gárdos-Orosz Fruzsina-Weller Mónika: Emberi Jogok Európai Bírósága; Adány Tamás Vince: Nemzetközi büntetöbíróságok stb.) is átfogó képet kap. Mindezek mellett a kötet nagy hangsúlyt fektet az emberi jogok tartalmának - jellemzően a jogokat generációkra osztó elmélet szerint történő - bemutatására. Az emberi jogok katalógusa időben és térben is sokféle volt és lehet, általánosságban azonban az emberi jogi katalógus bővülése figyelhető meg (20.). A kötet figyelmet szentel a vitatott alapjogok (Zakariás Kinga: Emberi méltósághoz való jog) mellett az állati jogok problematikájának bemutatására is (Majtényi Balázs: Állati jogok kérdése). 
Az enciklopédia (nevéhez méltón: tudás-összefoglaló) több mint egy lexikon, de nem feladata, hogy eredeti, teljesen új ismereteket tartalmazzon, hanem hogy összefoglalja, amit tudunk. Nagyobb átfogó címszavakból áll, bővebb, mint a lexikon. A kötet nem tételes jogi munka, mégis áttekintést ad az olvasónak a jogi kérdésekről, alapvető kérdéseket tárgyal, és nem a napi jogot tartalmazza. A sokszínü, igényes tanulmányok a témakör teljes körü feldolgozására törekednek, amelyek révén az olvasó átfogó képet kap az emberi jogok jelentőségéről. A tanulmányok szerkezete, tagolása kitűnő, a jól elhelyezett utalások megkönnyítik a komplex, sokrétű anyag áttekintését és az összefüggések megértését.

A tanulmányok végén található, néhány tételből álló bibliográfia az adott témakör irodalmáról, a kötet végén található általános és gyüjteményes müvek válogatott bibliográfiája pedig a témakör egészéröl ad tájékoztatást azok számára, akik akár tudományos igénnyel, akár ismeretszerzés, tájékozódás céljából kívánnak foglalkozni a bemutatott területtel. A hivatkozási rendszer egységes elvek alapján került kidolgozásra. A kötet legnagyobb értéke a témakör teljességre törekvő bemutatása, ami a tanulás és az ismeretszerzés alapfeltétele.

$\mathrm{Az}$ enciklopédia a hazai jogtudományi szakirodalom különösen értékes gyöngyszeme, bátran használható az oktató-kutató munkát végzők számára, valamint a gyakorló jogászok mindennapi munkájában is. Ugyanakkor az enciklopédia a rendkívül érdekes, jól olvasható tanulmányaival szélesebb olvasóközönséget céloz. A tanulmányok stílusa gördülékeny, logikus vonalvezetésủ, így a nem jogászok számára is könnyen követhető, és hozzájárul az emberi jogokhoz kapcsolódó ismeretek bővüléséhez.

(Lamm Vanda szerkesztö: Emberi jogi enciklopédia. Budapest: HVG-ORAC, 2018, 747 o.)

Jámbor Adrienn PhD, Miskolci Egyetem Állam- és Jogtudományi Kar 